NIKICA BARIĆ, viši znanstveni suradnik

Hrvatski institut za povijest

UDK 94(497.11)"1941/1944"(093.2)

Zagreb, Opatička 10

327(497.5:497.11)"1941/1944"(093.2)

\title{
POLITIKA NEZAVISNE DRŽAVE HRVATSKE PREMA SRBIJI
}

\begin{abstract}
APSTRAKT: Prilog prikazuje kako su vlasti Nezavisne Države Hrvatske tijekom 1941. godine pratile razvoj događaja u Srbiji. Također je prikazana vanjska politika tadašnjeg Zagreba, koja je vođena na način da se ne dozvoli eventualno jačanje Srbije, što će ostati trajno obilježje hrvatske vanjske politike do kraja Drugog svjetskog rata.
\end{abstract}

Ključne riječi: Nezavisna Država Hrvatska, Srbija, 1941. godina

Slomom Kraljevine Jugoslavije i proglašenjem Nezavisne Države Hrvatske (NDH) ostvareni su ciljevi ustaškog pokreta koji je Srbe i Srbiju smatrao glavnom preprekom ostvarenju hrvatske državnosti. Zadovoljstvo zbog sloma Jugoslavije, koja je iz ustaške perspektive predstavljala proširenu Srbiju i sredstvo srpskog ugnjetavanja hrvatskog naroda, dobro je izraženo u uvodniku koji je u dnevniku Hrvatski narod objavljen povodom Vidovdana 1941. godine. U tom je članku navedeno da je Vidovdan „najveći srpski narodni blagdan“, koji objedinjuje dvije „snage srpstva“, odnosno osvetu Kosova i težnju za obnovom Dušanova carstva. Na kraju Prvog svjetskog rata Srbima je „versailleskim diktatom“ konačno uspjelo obnoviti Dušanovo carstvo. Nakon toga Hrvati su više od 20 godina slušali kako je Kosovo osvećeno kraj Kumanova i na Kajmakčalanu, dok su hrvatska djeca bila prisiljena slaviti Vidovdan, najveći srpski državni blagdan i spomendan srpskog junaštva. No, kako je zaključeno u uvodniku, Vidovdan 1941. Srbi ne mogu slaviti „kao prošlih godina“, jer je „nova Europa“ pod vodstvom Adolfa Hitlera i Benita Mussolinija, „dolično i pravedno kaznila balkansko leglo ubojica i ratnih upaljača“:

„Srušeno je, u Versaillesu i drugim pariškim zamcima obnovljeno i prošireno Dušanovo carstvo, koje je bilo postavljeno kao istočna zaštita zapadnih velevlasti protiv Njemačke. 'Junačka' srpska vojska besmrtno se i za sva vremena osramotila u 'ratu od 8 dana'. Srušena je i uništena Jugoslavija, velika laž i nasilje, Dušanovo carstvo našeg stoljeća. (...) Sada su Srbi prepušteni sebi i svojim vlastitim snagama. Udovoljeno je povijesnoj pravdi i probitku Evrope. (...) Vi- 
dovdan god. 1941. hrvatski je narod u svojoj Nezavisnoj Državi Hrvatskoj dočekao kao pobjednik, kao osvetnik Evrope“.'

Za hrvatsku stranu u tom je razdoblju važno pitanje bilo određivanja novih granica, pa tako i onih prema Srbiji. Njemačka vojna uprava u Srbiji tražila je da zbog praktičnih razloga Zemun, odnosno dijelovi istočnog Srijema ostanu pod njezinom upravom, iako u političkom smislu nije poricano hrvatsko pravo na to područje. No, nakon daljnjih traženja hrvatske strane, koja je imala potporu Siegfrieda Kaschea, njemačkog poslanika u Zagrebu, održani su novi hrvatsko-njemački pregovorima kojima je dogovoreno da to područje u potpunosti prijeđe pod hrvatsku vlast. ${ }^{2}$ U skladu s ovim 10. 10. 1941. kotari Stara Pazova i Zemun stavljeni su pod isključivu upravu $\mathrm{NDH} .^{3}$

Na području južno od rijeke Save granica prema Srbiji određena je činjenicom da je Bosna i Hercegovina ušla u sastav NDH. Odmah nakon što je krajem aprila 1941. hrvatska vlast uspostavljena u Sarajevu, pokrenuta je akcija da hrvatska vojska i oružništvo zaposjednu i Sandžak. Ovo je podržavalo i muslimansko stanovništvo tog područja, koje je insistiralo na svojoj povijesnoj povezanosti s bosansko-hercegovačkim muslimanima, te su tražili da budu priključeni Bosni i Hercegovini, odnosno hrvatskoj državi. Već početkom maja 1941. hrvatske snage zaposjele su dijelove Sandžaka i tamo uspostavile hrvatsku vlast. Za hrvatske težnje na tom području veliki je problem predstavljala prisutnost Talijana, odnosno činjenica da je upravo tim područjem prolazila demarkaciona crta koja je teritoriju bivše Jugoslavije razdvajala na njemačko i talijansko interesno područje. Rimskim ugovorima od 18. 5. 1941. talijanska strana nametnula je NDH nepovoljno razgraničenje na jadranskom području, kojeg je Zagreb bio prisiljen prihvatiti, a Talijani su krajem lipnja odbili i zahtjev Ante Pavelića za uključenje cijelog Sandžaka u sastav NDH. Nakon toga hrvatska strana morala se povući iz dijelova Sandžaka koji je bio pod njezinim nadzorom, ali su Hrvati zbog izbijanja ustanka u Crnoj Gori ostali na tom području do početka septembra 1941., kada su se povukli na istočnu granicu NDH, odnosno granicu Bosne i Hercegovine prema Crnoj Gori i Srbiji iz 1914. godine. ${ }^{4}$

Na području južno od rijeke Save hrvatske vlasti su za osiguranje granice prema Crnoj Gori i Srbiji 21. 7. 1941. osnovale Zapovjedništvo Vojne krajine u

${ }^{1}$ „Obnovljeno Dušanovo Carstvo bilo je djelo Versaillesa, Srpski Vidovdan 1941. godine“, Hrvatski narod, Glasilo Hrvatskog ustaškog pokreta, br. 134, Zagreb, 28. 7. 1941., 1.

${ }^{2}$ Vjekoslav Vrančić, Branili smo državu, Uspomene, osvrti, doživljaji, Knjiga druga, Washington D. C. 2006., 157-171.

${ }^{3}$ Zbornik dokumenata i podataka o narodnooslobodilačkom ratu jugoslovenskih naroda, tom I, knjiga 17, Borbe u Vojvodini 1941-1944 god., Beograd 1958., dok. br. 5.

${ }^{4}$ Opširnije o djelovanju uprave NDH u dijelovima Sandžaka tijekom 1941. vidjeti: Danilo Jauković, „Sandžak u Narodnooslobodilačkom ratu (I deo)", Vojnoistorijski glasnik, br. 4, Beograd 1960., 23-56.; Danilo Jauković, „Sandžak u Narodnooslobodilačkom ratu (II deo), Vojnoistorijski glasnik, br. 5, Beograd 1960., 3-33.; Bogdan Gledović, „Narodnooslobodilački pokret u Sandžaku u prvoj godini oslobodilačkog rata“, Vojnoistorijski glasnik, br. 2, Beograd 1972., 19-60. 
Sarajevu, koje je s posebnim postrojbama osiguravalo područje od Bijeljine do Trebinja, odnosno Cavtata. ${ }^{5}$ Predstavnici Zapovjedništva Vojne krajine su 21. 10. 1941. u Zagrebu posjetili vojskovođu Slavka Kvaternika, ministra hrvatskog domobranstva. Tijekom razgovora s Kvaternikom među ostalim je zaključeno da se osiguranje državne granice ,prema istoku“ ne može ograničiti isključivo na uski pojas uz granicu. Zato izgradnju i održavanje cesta i putova, kao i drugih objekata koji će služiti obrani istočne granice treba protegnuti sve do crte Brod-SarajevoMostar-Metković. Idućeg dana, 22. 10., predstavnici Vojne krajine primljeni su kod Ante Pavelića koji je zaključio da obrana istočne granice predstavlja jednu od najvažnijih državnih potreba, kojoj treba pokloniti „najveću pažnju“. Iako Zapovjedništvo Vojne krajine neće preuzeti sve ovlasti građanskih vlasti, ono će, zaključio je Pavelić, u okviru svog djelovanja poduzeti potrebno da se „,narod Vojne Krajine osposobi za napore hrabrih, otpornih i požrtvovnih krajišnika“. ${ }^{6}$ No, već i prije toga, u devetom mjesecu 1941., predstavnici građanskih vlasti, primjerice Velike župe Vrhbosna u Sarajevu, žalili su se Zagrebu da ustanova Vojne krajine nije djelotvorna i da, među ostalim, postoji preklapanje ovlasti vojnih i građanskih vlasti na tom području. Zato je već tada iznesen prijedlog o ukidanju Vojne krajine. ${ }^{7}$

Nema sumnje da je Vojna krajina trebala predstavljati poseban način nadzora nad granicom prema Srbiji i Crnoj Gori, što je pokazivalo da Zagreb upravo na tom području vidi mogućnost najveće ugroze NDH. No, s širenjem djelovanja četničkih i partizanskih snaga na tom području ubrzo će se pokazati da Vojna krajina ne može osigurati granicu NDH prema istoku. Početkom maja 1942. ukinuto je Zapovjedništvo Vojne krajine, odnosno preustrojeno je u Zapovjedništvo za utvrđivanje granice na području od Bosanske Rače i uz rijeku Drinu do Višegrada. ${ }^{8}$

Iako je Jugoslavija uništena kao država, a Srbija se našla pod njemačkom okupacijom, Zagreb je i u svojoj vanjskoj politici djelovao na način koji će Srbiju zadržati oslabljenom. NDH u savezništvu protiv Srbije nije mogla računati na suradnju s Mađarskom, budući da su Mađari nakon sloma Jugoslavije okupirali i anketirali Međimurje, što Zagreb nije htio priznati. Nasuprot tome upravo je zajednička suprotstavljenost Mađarskoj omogućila suradnju između NDH i Rumunjske, pri čemu je hrvatska strana pokazivala interes da Banat bude prepušten Rumunjima, nakon čega bi između Srijema i Banata bila uspostavljena nova hrvatsko-rumunjska granica. ${ }^{9}$

${ }^{5}$ Opširnije o Vojnoj krajini u NDH vidjeti: Mladen Colić, Takozvana Nezavisna Država Hrvatska, 1941., Beograd 1973., 224-226.; Nikica Barić, Ustroj kopnene vojske domobranstva Nezavisne Države Hrvatske, 1941.-1945., Zagreb 2003., 112-118.

${ }^{6}$ Hrvatski državni arhiv, Zagreb (dalje: HDA), Zbirka zapisa upravnih i vojnih vlasti NDH i Narodnooslobodilačkog pokreta (dalje: ZZ NDH/NOP), III-115/1595-1610, Zapovjedništvo Vojne krajine, Vojni odjel, Taj. Broj: 600/1941.

${ }^{7}$ Historijski muzej Bosne i Hercegovine, Sarajevo, Broj dokumenta 37, Dopis upućen dr. Andriji Artukoviću, ministru unutarnjih poslova NDH, 10. IX. 1941.

${ }^{8} \mathrm{~N}$. Barić, Ustroj kopnene vojske domobranstva NDH, 117.

${ }^{9}$ Marin Mihanović, ,Mađarsko pitanje u hrvatsko-rumunjskim odnosima od 1941. do 1944. godine: pokušaj obnove Male Antante“, Časopis za suvremenu povijest, br. 2, Zagreb 2001., 323.-354. 
I dobri odnosi NDH s Bugarskom temeljili su se na težnji za slabljenjem Srbije. Kako je 1941. izjavio Mladen Lorković, tada hrvatski ministar vanjskih poslova, ,jedna jaka Bugarska“ bit će jamstvo NDH da će Srbija i njezin eventualni utjecaj „,biti slabiji“. S druge strane bugarski dužnosnici smatrali su poželjnim da Sandžak uđe u sastav NDH, kako bi, na kraju, daljnjim širenjem Bugarske na jugoistočne dijelove Srbije, na tom području bila uspostavljena zajednička bugarsko-hrvatska granica. ${ }^{10} \mathrm{U}$ vezi s njemačkim planovima da uguše ustanak koji je izbio u Srbiji, jedan bugarski ministar je krajem septembra 1941. rekao hrvatskom poslaniku u Sofiji da Nijemci nisu ,pravo poznavali mentalitet Srba“, pa su pogrešno mislili da će se oni "lojalno ponašati“. Kako je zaključio taj ministar i za Bugare i za Hrvate zapravo je bolje da Srbi „prave nerede“, pa će se Nijemci s njima konačno „radikalno obračunati“. ${ }^{11}$

Hrvatska strana imala je svoje predstavnike koji su pratili stanje u Srbiji i u Beogradu obavljali druge potrebne poslove. Domobranski satnik Josip Lončarević već je u četvrtom mjesecu 1941. otputovao u Beograd kao hrvatski časnik za vezu pri njemačkom Zapovjedništvu 2. oklopne armije, a zatim je imao istu dužnost pri njemačkom zapovjedništvu za Srbiju. Istovremeno je u Zemunu djelovao Prijavni ured hrvatskog domobranstva, na čijem se čelu nalazio potpukovnik Miroslav Schlacher. Do kraja 1941. Schlacher je preuzeo i dužnost časnika za vezu pri njemačkom zapovjedništvu za Srbiju. ${ }^{12}$

Jedna od glavnih dužnosti hrvatskog časnika za vezu pri njemačkim zapovjedništvima u Beogradu, kao i Prijavnog ureda hrvatskog domobranstva u Zemunu, bilo je organizirati preseljenje Hrvata, pripadnika bivše jugoslavenske vojske, odnosno njihovih obitelji, iz Srbije, odnosno istočnih dijelova bivše Jugoslavije u NDH. ${ }^{13}$

Osim toga Ministarstvo vanjskih poslova NDH je 25. 7. 1941. odredilo da djelatnik tog ministarstva Tihomir Vincetić preuzme dužnost ravnatelja ureda za putnice u Beogradu. Tako je u Beogradu uspostavljeno tijelo koje je nosilo naziv „Hrvatski klub - Ured za putnice“, dok je koristilo pečat s natpisom „Konzularno predstavničtvo Nezavisne Države Hrvatske - Beograd“ “. ${ }^{14}$ Čini se da se spomenuti ured zapravo nastavljao na „Hrvatski klub“, koji je kao udruženje djelovao u Beogradu za vrijeme Kraljevine Jugoslavije. ${ }^{15}$

${ }^{10}$ Nada Kisić Kolanović, Zagreb - Sofija, Prijateljstvo po mjeri ratnog vremena, 19411945., Zagreb 2003., 167.

${ }^{11}$ Poslanstvo NDH u Sofiji, Diplomatski izvještaji 1941-1945., Svezak 1, Priredila Nada Kisić Kolanović, Zagreb 2003., dok. br. 14.

${ }^{12}$ Aleksandar Vojnović, NDH u Beogradu, Zagreb 1995., 42-46.

${ }^{13}$ A. Vojinović, NDH u Beogradu, 42-46.; V. Vrančić, Branili smo državu, Knjiga druga, 157 .

${ }^{14}$ A. Vojnović, $N D H$ u Beogradu, 47-74.

${ }^{15}$ Nažalost raspolažem s malo podataka o predratnom „Hrvatskom klubu“ u Beogradu. No iz jednog njegovog dopisa od 25. 6. 1935. koji se čuva u fondu „Odvjetnička pisarnica Precca Nikola“ u Državnom arhivu u Zagrebu vidljivo je da je predsjednik tog kluba tada bio Pero Blašković. Klub je u istom razdoblju imao sjedište u palači „Luxor“, Balkanska ulica 4, drugi kat. 
Nakon njemačkog napada na Sovjetski Savez u Srbiji započinje djelatnost komunističkih ustanika, a na terenu su prisutne i četničke snage Draže Mihailovića, koje se pridružuju ustanku. Također postoji i četnička organizacija Koste Pećanca, koja nije sudjelovala u ustanku. Nijemci su nakon okupacije Srbije u njoj uspostavili Savjet komesara. Zbog ustanka se stanje u Srbiji pogoršalo, pa je krajem avgusta 1941. osnovana nova vlada na čelu s generalom Milanom Nedićem. ${ }^{16}$ Ovi događaji privukli su pažnju spomenutih hrvatskih predstavnika u Beogradu i Zemunu, o čemu su izvještavane nadležne vlasti u Zagrebu.

Domobranski satnik Josip Lončarević je 1. 9. 1941. uputio izvješće vojskovođi Slavku Kvaterniku, u vezi s osnivanjem vlade Milana Nedića. On je zaključio da je to u ,punom smislu četnička vlada“, jer je navodno osnovana na temelju dogovora između njemačkih predstavnika i četničkog vojvode Koste Pećanca, štoviše zapravo je Pećanac ,premier ove vlade“. Istovremeno s ovim ubrzano traje i osnivanje „srbske vojske“. U vezi s ovakvim razvojem stanja Lončarević nije skrivao zabrinutost. On je naveo da postoje sve izraženije „simpatije njemačkih vlasti“ prema Srbima, što je „nevjerovatno, ali je istina“. Lončarević je zaključio da Nijemci znaju za „ustaške akcije“, pri čemu je mislio na zločine i nasilja nad Srbima u NDH, što na njemačkoj strani smanjuje simpatije prema Hrvatima, a povećava njihovu naklonjenost prema Srbima. Štoviše, postoje pouzdani podaci da „srbska vojska“, zajedno s četnicima, priprema prepad na istočnu Bosnu, pri čemu bi glavni pravac napada bio prema Zvorniku, a to bi imalo prešutnu potporu Nijemaca. Lončarević je također upozorio da Tihomir Vincetić, hrvatski vicekonzul u Beogradu, nesavjesno izdaje propusnice osobama koje u NDH namjeravaju uči sa ,specijalnim zadacima“. Zaključio je da podaci koje dostavlja, posebno onaj o prepadu koji će se iz Srbije izvršiti prema NDH, možda imaju „fantastičan izgled“, ali je ocijenio da bi ga trebalo shvatiti najozbiljnije, te bi u vezi s tim trebalo poduzeti žurne mjere. ${ }^{17}$

Njemački zapovjednik Srbije, general Heinrich Danckelmann, pozvao je 10. 9. 1941. na razgovor bugarskog, hrvatskog, mađarskog i talijanskog časnika za vezu. Tom prilikom on im je službeno priopćio da je po ,želji srbskih komesara“ postavio novu vladu, na čelu s časnim vojnikom, armijskim generalom Milanom Nedićem. Zadatak Nedićeve vlade je da u Srbiji uspostavi red i mir, jer nije zadaća njemačkih snaga u Srbiji da se bore protiv komunista. Zato je odobreno pojačanje žandarmerije i osnivanje „milicije“, koja će se suprotstaviti komunistima. Kako je objasnio Danckelmann, u susjednim državama proširile su se glasine da će Srbija dobiti svoju vojsku s teškim naoružanjem. No, „milicija“ u Srbiji imat će samo puške, ručne bombe i lake strojne puške. „Izmišljotina“ je, istaknuo je Danckelmann, da će spomenute snage biti opremljene topništvom ili zrakoplovstvom. Ako tim snagama bude potrebna potpora u teškom naoružanju, nju će

${ }^{16}$ Bojan B. Dimitrijević, Vojska Nedićeve Srbije, Oružane snage srpske vlade 19411945, Beograd 2011., 13-131.

${ }^{17}$ A. Vojnović, NDH u Beogradu, 60-62. 
osigurati njemačka vojska. Formiranje novih snaga vrši se u Beogradu, na prijedlog Nedića i po odobrenju Danckelmanna, koji će također određivati kako će se nova „milicija“ raspoređivati na terenu. Kada Srbija bude očišćena od komunista u svakom sjedištu banovine i sreza postojat će po jedno odjeljenje „milicije“, čija će snaga biti 150 ljudi. Ove snage osiguravat će državne zgrade, željezničke pruge, a po potrebi će djelovati i kao pokretne jedinice. ${ }^{18}$

Potpukovnik Schlacher, glavar Prijavnog ureda hrvatskog domobranstva u Zemunu, u izvješću od 12. 9. 1941. izvijestio je Glavni stožer domobranstva u Zagrebu o primanju kod generala Dankelmanna. I Schlacher, slično kao i satnik Lončarević, nije skrivao zabrinutost zbog činjenice da Srbija stvara nove vojne snage. On je raspolagao podacima da nova „milicija“ odnosno „srpska vojska“ već ima 8000 dobro opremljenih ljudi, dok bi do kraja listopada 1941. taj broj trebala narasti na čak 65.000 ljudi, a Srbima je navodno odobreno da ustroje i 18 topničkih bitnica. Sve je to prelazilo podatak o 4000 ljudi, koje je spomenuo general Dankelmann. Zato je Schlacher zaključio da je osnivanje ovih snaga izvršeno bez njemačkog znanja, ili su Nijemci navodili puno manji broj novih srbijanskih snaga „radi umirenja susjednih zemalja“. Ipak je, na temelju nekih podataka, Schlacher iznio i mišljenje da osnivanje nove vlade i „srbske vojske“ neće imati uspjeha jer su neredi u Srbiji poprimili široke razmjere i ne može se vjerovati da će ih ugušiti trenutno slabe njemačke snage ili nova „,srbska milicija“. ${ }^{19}$

Prijavni ured hrvatskog domobranstva u Zemunu je u obavještajnom izvješću o stanju u Srbiji od 25. 9. 1941. naveo da se general Ljuba Novaković sukobio s generalštabnim pukovnikom Dražom Mihailovićem, koji je Novakovića optužio da je „komunist i plaćenik Moskve“. Zato je Mihailović navodno osudio Novakovića na smrt, pa je ovaj pobjegao u Crnu Goru. ${ }^{20} \mathrm{U}$ istom je izvješću o samom Mihailoviću navedeno da se nalazi na području Homolja, s namjerom da to područje „očisti od komunističkih bandi“, ali je za to navodno preslab. Prema drugim podacima Mihailović se nalazi na području prema Zvorniku. Tamo navodno organizira četničke jedinice koje prebacuje preko granice u Bosnu. U izvješću je izneseno mišljenje da bi ovaj drugi podatak mogao biti točan jer se „razni četničko komunistički odredi“" u Srbiji nalaze u nepovoljnom položaju i progone ih njemačke snage. Također se raspolagalo s podatkom da se bivši jugoslavenski žandarmerijski major Jezdimir Dangić s 500 ,oružnika Srbijanaca prebacio u Bosnu“. O samom Dangiću i njegovom djelovanju hrvatska strana već je imala podataka, a u spomenutom izvješću navedeno je da je o svemu tome obaviještena i njemačka vojna obavještajna služba u Beogradu. Također je bilo podataka da u okolici Šapca traju „veliki neredi“ i da njemačka vojska na tom području

${ }^{18}$ Zbornik dokumenata i podataka o narodno-oslobodilačkom ratu jugoslovenskih naroda, tom I, Borbe u Srbiji 1941. god., Beograd 1949., dok. br. 153.

${ }^{19}$ Isto.

${ }^{20}$ HDA, ZZ NDH/NOP, III-18/661-662, U. N.S., U. O.S., Ured II, Broj: 02550/1941. Za podatke o generalu Ljubi Novakoviću vidjeti: Mile S. Bjelajac, Generali i admirali Kraljevine Jugoslavije 1918-1941., Studija o vojnoj eliti i biografski leksikon, Beograd 2004., 231. 
vrši akciju čišćenja terena, dok put između Šapca i Beograda i dalje nije otvoren za promet. Osim toga jedna skupina komunista je dana 24. 9. navodno napala 14. kvart, odnosno policijsku stanicu u Beogradu, kojeg je „zapalila“. ${ }^{21}$

$\mathrm{U}$ istom je razdoblju u sklopu njemačkih napora da uguše ustanak u Srbiji u nekim slučajevima došlo i do sudjelovanja hrvatskih snaga. Tako je Zapovjedništvo ustaške bojne u Hrvatskoj Mitrovici u brzojavu koji je u Zagrebu primljen 25. 9. 1941. navelo:

„Na hitan poziv njemačkog zapovjedništva uputio sam noćas dvije satnije u pomoć u Šabac. Naši su na juriš zauzeli jednu veliku tvornicu i oslobodili Hrvate radnike i namještenike. Sada su došle njemačke motorizirane čete u pomoć. Šabac se bombardira upaljivim bombama i gori. Do sada smo bez gubitaka. Iz Šapca sam se vratio posle podne. Satnije ostale na položaju“. ${ }^{22}$

Prijavni ured hrvatskog domobranstva u Zemunu je 5. 1. 1941. izvijestio Ustašku nadzornu službu u Zagrebu o podacima koji su, putem hrvatskog vicekonzula Vincetića, dostavljeni od jednog ,,agenta“. Prema tim podacima vlakom je iz Beograda za Zagreb prebačena, ,jedna mala paklena mašina“. Isti agent javljao je da u Srbiji djeluju snažne njemačke snage koje će ubrzo uništiti četnike i komuniste. No, Srbi se ipak mogu nadati pomoći Velike Britanije i oni će čekati povoljan trenutak da se osvete Nijemcima. Potpukovnik Schlacher zaključio je da spomenuti podaci nisu ,inteligentni“, odnosno uglavnom su ,proizvoljni“ i temelje se na „uličnim pričama“. Zatražio je da se Zagreb u buduće za sve podatke o stanju u Beogradu i sjevernoj Srbiji obraća Prijavnom uredu hrvatskog domobranstva u Zemunu. U slučaju da u Beogradu djeluju hrvatski agenti, odnosno osobe sa ,specijalnim misijama“, zatraženo je da Prijavni ured o tome bude obaviješten, odnosno da ti agenti budu upućeni na spomenuti ured, kako bi i on mogao nadzirati njihov rad. ${ }^{23}$

Domobranski potpukovnik Adam Petrović, vojni izaslanik pri Poslanstvu NDH u Sofiji, krajem novembra 1941. izvijestio je Zagreb o podacima do kojih je došao, pri čemu je upozorio da su oni samo djelomično provjereni. Tako je naveo da u Srbiji i dalje traju ,nemiri u punom opsegu“. „Najkarakterističniju ličnost" u Srbiji predstavlja pukovnik Draža Mihailović, inače bivši jugoslavenski vojni izaslanik u Bugarskoj. Mihailović je i „četnik i komunista“, a „nesretni i uzbuđeni živalj Srbije“ u njega polaže „mnogo nade“. Mihailovićevi „komunističko-četnički podhvati“ prijete da u Srbiji izazovu „građanski pokolj“, jer su njegovi suparnici i general Milan Nedić i Kosta Pećanac, koji su podjednako željni odigrati „važnu ulogu za spas Srbije“. Tako je Mihailović označen kao vođa komunističke agitacije i organizator svih četničkih akcija, a zaključeno je da će opisana suparništva između spomenutih istaknutih osoba i njihov „egoizam“ imati teške posljedice za samu Srbiju, odnosno njezin narod. ${ }^{24}$

${ }^{21}$ HDA, ZZ NDH/NOP, III-18/661-662, U. N.S., U. O.S., Ured II, Broj: 02550/1941.

${ }^{22}$ HDA, Ministarstvo unutarnjih poslova NDH, I. A., Broj: 235/1941.

${ }^{23}$ HDA, ZZ NDH/NOP, III-18/719-720, Prijavni ured hrvatskog domobranstva, Zemun, V. T. Broj: 256/1941.

${ }^{24}$ A. Vojinović, NDH u Beogradu, 72-73. 
U sklopu gušenja ustanka u Srbiji njemačka vojska je početkom decembra 1941. izvela napad na Mihailovićev štab na Ravnoj Gori, ali je Mihailović uspio izbjeći zarobljavanje, te se povukao prema Sandžaku. ${ }^{25}$ Njemačke vojne vlasti u Srbiji o ovome su obavijestile Zagreb, te je Glavni stožer Ministarstva hrvatskog domobranstva 10.12. 1941. posebnom okružnicom o tome obavijestio i dao upute podređenim zapovjedništvima. U okružnici je navedeno da je stožer Draže Mihailovića zarobljen 20 kilometara jugoistočno od Valjeva. Sam Mihailović navodno je „pobjegao iz Užica“, prema zapadu, odnosno sjeverozapadu. Nagrada za hvatanje Mihailovića iznosi 200.000 dinara, a u slučaju da uđe u NDH treba ga odmah uhititi. U vezi s ovim objašnjeno je da je Mihailović glavnostožerni pukovnik bivše jugoslavenske vojske i zapovjednik ,četnih skupina“. Jugoslavenska emigrantska vlada u Londonu promaknula ga je u čin generala i imenovala zapovjednikom „obnovljene jugoslovenske vojske na cielom području bivše jugoslovenske države". Prema posljednjim podacima Mihailovićev stožer nalazio se na Ravnoj Gori u Srbiji. Također je upozoreno da su četničke skupine u istočnoj Bosni, kojima zapovijeda Jezdimir Dangić, s Mihailovićem održavale „tijesnu vezu“, te nije isključena mogućnost da će se Mihailović pokušati skloniti upravo na području istočne Bosne. ${ }^{26}$ Prethodno navedeni podaci, iako nerijetko netočni, pokazuju zanimanje hrvatskih vlasti za razvoj stanja u Srbiji i kako će se događaji u njoj odraziti na stanje u NDH.

Može se reći da je kapitulacija Kraljevine Italije u septembru 1943. donijela određene promjene u politici NDH prema Srbiji. Talijanski slom omogućit će hrvatskoj strani da povrati vlast nad većinom područja koja su Talijanima pripali na temelju Rimskih ugovora. ${ }^{27}$ Isto tako nestanak talijanskog utjecaja u Crnoj Gori i Albaniji otvorit će za NDH prostor za pokušaj razvijanja vlastite akcije na tom području, čiji je konačni cilj opet bio spriječiti eventualno jačanje Srbije kao političkog i vojnog čimbenika. U istom je razdoblju Hermann Neubacher postavljen za posebnog opunomoćenika njemačkog Ministarstva vanjskih poslova za europski Jugoistok. Na toj dužnosti on je pokazao spremnost za jačanje položaja vlade generala Nedića, odnosno Srbije. ${ }^{28}$

Tako je Zagreb nakon kapitulacije Italije pružio potporu crnogorskom političaru Sekuli Drljeviću, koji je tada u NDH osnovao Crnogorsko državno vijeće, kao temelj za uspostavu samostalne Crne Gore. U vezi s ovim neka njemačka tijela zaključit će da Hrvati pružaju potporu Drljeviću kako bi spriječili da Nedićeva Srbija preko Crne Gore eventualno izbije na Jadran, čime bi uloga Srbije

25 Jozo Tomasevich, Četnici u Drugom svjetskom ratu 1941-1945, Zagreb 1979., $182-183$. 261/1941.

${ }^{26}$ HDA, Oružnički vodovi NDH, Zapovjedništvo oružničkog voda Knin, Taj. Broj:

${ }^{27} \mathrm{O}$ utjecaju kapitulacije Italije na stanje u NDH vidjeti: Bogdan Krizman, Ustaše i Treći Reich, Prvi svezak, Zagreb 1983.

${ }^{28}$ J. Tomasevich, Četnici u Drugom svjetskom ratu, 284-288. Također vidjeti: Herman Nojbaher, Specijalni zadatak Balkan, Beograd 2005. 
ostala beznačajna. Kasche, njemački poslanik u Zagrebu, bio je spreman Drljeviću pružiti potporu, ali Neubacher za to nije bio zainteresiran. ${ }^{29}$

Početkom 1944. u hrvatskom tisku ponovno je problematizirano i pitanje pripadnosti Sandžaka. Tako se navodilo da Srbija ne smije ovladati Crnom Gorom, nakon čega bi „bacila oko“ na Albaniju. NDH ne smije biti odvojena od Albanije i Crne Gore, te je zato nužno da Sandžak ostane „kopča i veza između Hrvatske, Crne Gore i Albanije, njihov put i njihova obrana“. U tom smislu Sandžak čini dio „dinarsko-hrvatskog geopolitičkog područja“, pa ne može biti prepušten u sastav „moravske Srbije“. 30

U vezi s ovim zanimljiv je i problem do kojeg je došlo početkom 1945., kada je Crnogorsko državno vijeće u Zagrebu od sandžačkih muslimana tražilo da se izjasne kao Crnogorci. Zato su se ti muslimani obratili hrvatskim dužnosnicima od kojih su tražili da se njihov položaj u NDH odredi nezavisno od akcije Drljevića i njegovog vijeća. Ubrzo je Ante Pavelić odredio da se muslimani iz Sandžaka trebaju smatrati „inozemnom hrvatskom skupinom“, te će dobiti dozvole boravka u NDH u kojima će biti označeni kao „Sandžaklije“, a ne kao „Crnogorci““. ${ }^{31}$

Nakon talijanske kapitulacije došlo je i do proglašenja nezavisne Albanije, čemu su Nijemci pružili potporu. U vezi s ovim poslanik Kasche je krajem 1943. iz Zagreba izvijestio Berlin da hrvatske vlasti imaju pozitivno stajalište prema nezavisnoj Albaniji. Nasuprot izraženim „velikosrpskim tendencijama“ hrvatske vlasti dobre odnose s Tiranom smatraju korisnima i zato se može očekivati da će Zagreb priznati albansku državnost. Početkom 1944. hrvatska strana zatražila je da u Tirani otvori svoj generalni konzulat. No, Neubacher se ni s ovim nije složio. On je ocijenio da ne postoje opravdani razlozi da NDH u Tirani ima svoje predstavništvo, zaključujući da bi bila riječ isključivo o obavještajnom tijelu, koje na tom području nije poželjno. ${ }^{32}$

Uzimajući u obzir sve spomenuto ne iznenađuje da je domobranski pukovnik Dragan Andrić, hrvatski časnik za vezu pri njemačkom Zapovjedništvu jugoistoka u Beogradu, početkom 1944. zaključivao da Nijemci vode dvije politike, ,protusrbsku“, čiji je predstavnik SS-general August Meyszner, zapovjednik njemačke policije u Srbiji, i „,srbofilsku“, čiji je predstavnik Neubacher ${ }^{33}$ Kada je nedugo kasnije Meyszner iz Srbije povučen u Berlin pukovnik Andrić zaključio je da je njegovim odlaskom hrvatska strana izgubila „velikog prijatelja“, ocjenju-

${ }^{29}$ Radoje Pajović, „Politička akcija Sekule Drljevića i njegova saradnja sa ustaškim vođstvom i njemačkim poslanstvom u Zagrebu (1943-1945)“, Časopis za suvremenu povijest, br. 1, Zagreb 1971, 75-89.

${ }^{30}$ Nada Kisić Kolanović, Muslimani i hrvatski nacionalizam, 1941-1945., Zagreb 2009., $55-57$.

${ }^{31}$ Historijski muzej Bosne i Hercegovine, Broj dokumenta: 3943, NDH, Ministarstvo unutarnjih poslova, Glavno ravnateljstvo za javni red i sigurnost, Odsjek II B, Broj: V-1703/1945., IV/2.

32 Živko Avramovski, „Treći Reich i 'Velika Albanija' posle kapitulacije Italije (19431944)“, Radovi Instituta za hrvatsku povijest Sveučilišta u Zagrebu, 9, Zagreb 1976., 93-213.

${ }^{33}$ HDA, ZZ NDH/NOP, III-18/477-513, NDH, Ministarstvo oružanih snaga, Izvještajni odjel, Izvj. Taj. Broj: 2919/1944. 
jući da bi, kako bi bila održana ravnoteža, Srbiju trebao napustiti i Neubacher, kao vođa „,srbofilske politike“. ${ }^{34}$

U izvješćima pukovnika Andrića iz istog razdoblja neprestano se isticala opasnost od jačanja Srbije i štete koju to može imati za NDH. Tako je u izvješću o stanju u Srbiji tijekom februara 1944. Andrić naveo da politika Nedićeve vlade „ostaje ista“, odnosno ona teži širenju Srbije na račun susjeda. Andrić je zaključio da je to u skladu s tradicionalnom politikom srpskog naroda, koja je bila i ostat će „Zavojevačka“, odnosno imperijalistička. Budući da vlada ne može opstajati protiv volje svoga naroda, tako i svaka vlada u Srbiji, bez obzira na to tko su njezini članovi i koje je njihovo političko opredjeljenje, mora težiti ,zavojevačkim ciljevima“. U tom smislu taktika svake srbijanske vlade može se samo prividno izmijeniti, ali niti jedna ne može odustati od „zavojevačkih ciljeva“ vlastitog naroda, ako želi zadržati njegovu potporu. Kako bi te ciljeve ostvario Nedić je djelovao i nadalje djeluje „sustavno“, na prvom mjestu novinskom i drugom promidžbom, zatim sređivanjem prilika u Srbiji i jačanjem vlastitih vojnih snaga koje će iskoristiti za ostvarenje svojih ciljeva. ${ }^{35}$ Slično ovome pukovnik Andrić je i u izvješću o stanju tijekom marta 1944., razmatrajući istaknute osobe u Srbiji naveo:

„U Srbiji ne može postojati ni jedna stranka, koja ne bi vodila izričitu srbsku imperialističku politiku. U tome se slažu [Milan] Nedić i [Draža] Mihailović i [Dimitrije] Ljotić. Da bi to postigli, počinju time, da se služe sva trojica lažnom promičbom, čisto na bizantinski način. Tako na primjer, Hrvate optužuju kod Niemaca, da su komunisti, kod Rusa Srbi rade panslavističkim smjerom, kod anglo-amerikanaca sa demokracijom"“. ${ }^{36}$

Ovakva razmišljanja postojat će i u posljednjim mjesecima rata. Krajem 1944. Srbija je pala u ruke Titovih partizana. General Nedić povukao se u Beč, dok su Nijemci osigurali da se Srpski dobrovoljački korpus, koji se u Srbiji pokazao pouzdanim u borbama protiv partizana, povuče na područje njemačkog Operativnog područja Jadransko primorje, koje je nakon kapitulacije Italije uspostavljeno na području dotadašnjih sjeveroistočnih talijanskih pokrajina. Nakon povlačenja iz sjeverne Dalmacije i Like, početkom 1945. na to je područje stigla i Dinarska četnička divizija vojvode Momčila Đujića. Postojala je inicijativa da se ove srpske snage udruže sa slovenskim protukomunističkim snagama, kako bi postali temelj obnovljene kraljevske jugoslavenske vojske, koja bi se spojila sa zapadnim saveznicima i zatim suprotstavila Titovim partizanima. ${ }^{37}$ Hrvatska strana primijetila je ovu mogućnost, a zabrinutost zbog takvog

${ }^{34}$ HDA, ZZ NDH/NOP, III-18/415-452, NDH, Ministarstvo oružanih snaga, Izvještajni odjel, Izvj. Taj. Broj: 3825/1944.

${ }^{35}$ HDA, ZZ NDH/NOP, III-18/413-475, NDH, Častnik za vezu kod Zapovjednika jugoiztoka, Beograd, Taj. Broj: 103/1944.

${ }^{36}$ HDA, ZZ NDH/NOP, III-18/477-513, NDH, Ministarstvo oružanih snaga, Izvještajni odjel, Izvj. Taj. Broj: 2919/1944.

${ }^{37}$ B. B. Dimitrijević, Vojska Nedićeve Srbije, 446-448. 
razvoja događaja jasno je istaknuta u izvješću Glavnog ravnateljstva za javni red i sigurnost u Zagrebu od 5. 3. 1945., u kojem je zaključeno da koncentracija srpskih i slovenskih protukomunističkih snaga u Operativnom području Jadransko primorje može imati dalekosežne negativne posljedice za NDH. U izvješću je navedeno da je Srbima pošlo za rukom uvjeriti Nijemce da su oni jedini južnoslavenski narod koji je uvjereni protivnik komunizma, pa su ih Nijemci pred napredovanjem partizana smjestili u Operativno područje Jadransko primorje. S druge strane Srbi se pripremaju za trenutak kada će doći do njemačkog sloma i povlačenja s tog područja. Zatim će se srpski i slovenski protukomunisti preustrojiti u novu jugoslavensku vojsku, koja bi na slovenskom području u svoje redove u kratkom vremenu mogla mobilizirati čak 300.000 ljudi. U povoljnom trenutku te će snage krenuti u zauzimanje hrvatskih krajeva, a zatim će pokušati osloboditi i Srbiju od komunističke vlasti, pri čemu se nadaju potpori zapadnih saveznika, koji i sami žele suzbiti sovjetski utjecaj. U skladu s ovim u tom je izvješću zaključeno da prisutnost srpskih snaga na slovenskom području predstavlja najozbiljniju opasnost za ,hrvatsku državnu samostalnost, pa i za sam obstanak hrvatskog naroda“". ${ }^{38}$ No, ova vrsta ugroze NDH na kraju se nije ostvarila, te je njezin slom došao od strane Titovih snaga, dok su istu sudbinu doživjele i srpske i slovenske protukomunističke snage.

\section{Zaključak}

Politika NDH prema Srbiji je dosljedno išla za tim da onemogući bilo kakvo jačanje političkog i vojnog položaja tadašnjeg Beograda. Hrvatski predstavnici bili su zabrinuti što su Nijemci 1941. dozvolili osnivanje oružanih snaga srbijanske vlade, iako nije bila riječ o pravoj vojsci. $U$ istom je smjeru vođena je $\mathrm{i}$ hrvatska politika dobrih odnosa sa svim čimbenicima kojima je oslabljena Srbija također odgovarala, primjerice s Bugarskom, dok se nakon kapitulacije Kraljevine Italije za Zagreb otvara mogućnost razvoja takvih odnosa i s pojedinim crnogorskim političkim čimbenicima, kao i težnja uspostave veza s obnovljenom albanskom državom. U okolnostima sloma Kraljevine Jugoslavije i njemačke okupacije Srbije nesumnjivo je NDH bila u neusporedivo povoljnijem položaju, kao nova nezavisna država uklopljena u sastav ,novog europskog poretka“. Kasnija unutarnja nestabilnost NDH, ekspanzionistička politika njezinog formalnog talijanskog saveznika i sve veće zavisnost tadašnjeg Zagreba od Nijemaca i njihovih vojnih i drugih institucija uveliko su oslabili položaj hrvatske strane. U tom smislu bila je vidljiva zabrinutost da bi određeni dijelovi njemačke politike mogli početi davati veću važnost Srbiji, pa ne iznenađuje nepovjerenje hrvatske strane prema njemačkom predstavniku Hermannu Neubacheru, koji je zastupao stajalište potrebe većeg njemačkog oslonca na srpske protukomunističke snage.

${ }^{38}$ HDA, Ustaška vojnica, NDH, Ministarstvo oružanih snaga, Stožer Ustaške vojnice, Izvještajni odjel, Broj: 861/1945. 
Nikica Barić

\section{INDEPENDENT STATE OF CROATIA AND SERBIA}

\section{Summary}

The article presents how the authorities of the Independent State of Croatia (ISC) observed the situation in Serbia during 1941. Throughout the existence of the ISC its foreign policy aimed at preventing any possibly strengthening of Serbia who was, after the collapse of Yugoslavia kept under German occupation. The article gives only the brief presentation of few ISC documents dealing with the situation in Serbia but it can be assumed that a more thorough research of various ISC intelligence reports dealing with Serbia could give new information interesting for the history of Serbia during World War II. 